\title{
Dense Wild Yam Patches Established by Hunter-Gatherer Camps: Beyond the Wild Yam Question, Toward the Historical Ecology of Rainforests
}

\author{
Hirokazu Yasuoka
}

Published online: 16 March 2013

(C) The Author(s) 2013. This article is published with open access at Springerlink.com

\section{Introduction}

Prior to the 1980s, most researchers believed that the African forest hunter-gatherers, or Pygmies, were the original inhabitants of the central African rainforests. It was assumed that their close social, economic, and ecological relationships with neighboring agricultural societies did not date back long, and that they had previously lived solely through foraging wild forest products. The same is true for forest hunter-gatherers on other continents.

However, Headland (1987) and Bailey et al. (1989) noted that no previous studies had produced sound evidence that pure hunter-gatherer subsistence was possible in any rainforests worldwide, and they argued that it was not, and had never been, possible to live in such areas while solely depending on wild products. Although rainforests contain vast numbers of species and huge biomass, consumable resources for humans, especially sources of calories, seem to be scarce and dispersed. Therefore, they argue, hunter-gatherers adapted to live in rainforests only after they began obtaining agricultural crops from cultivators. This hypothesis was called the "wild yam question" by Headland (1987) because the availability of wild yams was considered to be the key factor that determined whether pure hunter-gatherer subsistence in rainforests was viable.

Two opposing arguments have arisen from studies in different regions of the Congo Basin. Hart and Hart (1986) concluded that it was extremely difficult for the Mbuti in the Ituri forest in the eastern Congo Basin to live without agricultural crops, particularly in the dry season and the early rainy season when wild nuts and honey were not available. On the other hand, Bahuchet et al. (1991),

H. Yasuoka

Centre d'Ecologie Fonctionnelle et Evolutive, CNRS UMR5175, Montpellier 34293, France

H. Yasuoka $(\bowtie)$

Hosei University, Tokyo 102-8160, Japan

e-mail: yasuoka@hosei.ac.jp
Hladik and Dounias (1993), and Sato (2001, 2006) argued that for the Aka and Baka in the western Congo Basin enough wild yams existed for their subsistence. These studies were principally based on investigations of the density of wild yams, and lacked detailed descriptions of the use of wild yams. Therefore, the issue of whether exploitation of wild yams, including searching for them, digging them up, transporting them to the camp, and cooking and consuming them, could have been practiced in everyday life remains inconclusive (cf. Bailey and Headland 1991).

Archaeological studies have provided powerful evidence indicating the existence of humans in the African rainforests before the beginning of agriculture (Mercader 2003a, b; Mercader and Martí 2003). Unfortunately, they did not identify the foods upon which the ancient forest huntergatherers depended. They referred to ecological and anthropological studies that suggested ancient hunter-gatherers would have eaten wild nuts and meat, both of which were considered to have limited availability (Hart and Hart 1986).

The simplest and most explicit way to demonstrate if and how hunter-gatherers can live on a diet consisting mostly of wild yams is to actually observe it. During fieldwork with the Baka in southeastern Cameroon, I (2006a; 2009a) recorded all of the harvests during long-term and large-scale hunting-and-gathering camps (molongo in the Baka language) in the dry and early rainy season, i.e., the period during which the forest was thought to be barren (Hart and Hart 1986), and found that the forest provided a plentiful food supply, $65 \%$ of which (on a calorie basis) was made up of wild yams, and in particular annual species. Furthermore, Sato et al. (2012) undertook controlled huntingand-gathering camping with Baka informants and demonstrated that annual yams are a staple food throughout the year.

However, the question remains as to how yams have become so densely distributed in this area. I (2009a) noted that, within the area containing numerous yam patches, small settlements had been created before the colonial period. Moreover, the forests of Cameroon have been considerably 
disturbed by shifting cultivation for centuries (Chujo 1992; Van Gemerden et al. 2003), and contain many trees that prefer a disturbed environment (Yasuoka 2009b). Therefore, it is possible that forest disturbances via shifting cultivation might have affected the distribution of light-demanding annual species of wild yam (Yasuoka 2009a).

It is of interest whether such disturbances were indispensable for the development of sufficient yam patches to support the hunter-gatherers. In 2012, a Baka informant told me that he had passed by molongo campsites where around 100 people had consumed numerous yams in 2002 and 2005 (Yasuoka 2006a, 2009a) and found dense distributions of wild yams that had regenerated from the inedible parts of tubers discarded during cooking. Hence, for the present study, I revisited these campsites. By adding quantitative data obtained from previous studies, it was possible to determine whether the actions of hunter-gatherers themselves can generate sufficient yam patches for the annual molongo lifestyle simply through the exploitation and subsequent dispersal of wild yams. This examination moves beyond previous issues regarding the notion of pure hunter-gatherer subsistence to the perspective of an historical ecology that focuses on the history of interaction between humans and resources.

\section{People and Study Sites}

The Baka make up one of the so-called Pygmy groups scattered across the Congo Basin. Baka territory straddles southeastern Cameroon, northwestern Congo-Brazzaville, and northeastern Gabon, and is covered with rainforest on gently rolling hills at an altitude of 400-600 m above sea level. The vegetation is classified as a mixture of evergreen and moist semideciduous forests (Letouzey 1985a, b) dominated by the families Caesalpinioideae, Mimosoideae, Annonaceae, and Meliaceae (Yasuoka 2009b). The mean annual temperature is around $25^{\circ} \mathrm{C}$ and tends to be constant year-round. The mean annual rainfall at Yokadouma is about $1,500 \mathrm{~mm}$. The mean monthly rainfall in the dry season (from December to February) is less than $50 \mathrm{~mm}$, whereas in the rainy season (from March to November) it is normally more than $100 \mathrm{~mm}$, although the months of June and July are typically drier.

Although there has not been a recent census of the Baka population, it is estimated to be around 30,000 in southeastern Cameroon (Njounan Tegomo et al. 2012). Thirteen groups of Bantu-speaking cultivators and two groups of Adamawa Eastern-speaking cultivators have close social and economic relationships with the Baka, as is the case with other Pygmy groups (Hewlett 1996). After the 1930s, a French mandate government promoted the sedentarization of both Baka and the cultivators, and this policy was continued by the Cameroonian government after independence in 1960 (Althabe 1965). Starting in the 1970s, the populations began to settle along the country's unpaved highways, and today most Baka live in sedentary settlements along roads, although they spend some months a year in the forest.

I conducted field research in June 2012 in Zoulabot Ancien village, Boumba-Ngoko Department, East Region, Cameroon (Fig. 1). The village is located between two highways, separated by about $150 \mathrm{~km}$ and running from north to south in southeastern Cameroon. As of June 2012, it contained four Baka settlements of 191 people comprising 41 households. In addition, the Konabembe, a Bantu group, also live in the village (50 people comprising 12 households), including schoolchildren that spend most of the year in the town. Many of the Konabembe families had moved to villages near Yokadouma in the 1970s, but returned after the construction of a logging road in 2002.

\section{Materials and Methods}

\section{Wild Yams on Baka Land}

According to previous studies, 15 to 17 species of wild yam (genus Dioscorea) and two species of yam-like plants (genus Dioscoreophyllum) grow in the forests of Cameroon (Hladik and Dounias 1993; Dumont et al. 1994; Hamon et al. 1995). Among them, 10 edible species of Dioscorea (Table 1) and one edible species of Dioscoreophyllum have been recorded growing on Baka land. D. praehensilis and D. semperflorens are the most important species in the Baka diet (Table 2). These species are annuals that have annual stems and tubers with starch reserves that peak during the dry season (Hamon et al. 1995; McKey et al. 1998; Dounias 2001). Therefore, in the study area, the period from November to April is suitable for the harvesting of these yams (Dounias 2001; Yasuoka 2006a). In general, annual species tend to grow in drier and more open environments; however, D. praehensilis and D. semperflorens are also distributed in forest areas (Dumont et al. 1994; Hamon et al. 1995; Dumont 1997). Among the species that have perennial stems and tubers and grow mostly in densely forested areas, D. burkilliana and D. mangenotiana are the most important in the Baka diet (Table 2). Their tubers reach the maximum size on an irregular basis so they are harvestable throughout the year. All these species multiply through sexual propagation, using winged seeds that spread out to surrounding areas. Some of them use vegetative propagations, i.e. via bulbils or stolon (Table 1). In addition, all of them can be reproduced by transplanting parts of tubers.

Investigation of the Distributions and Densities of Wild Yams

The distributions of wild yams were investigated at two long-term molongo campsites (Mongungu and Jalope 


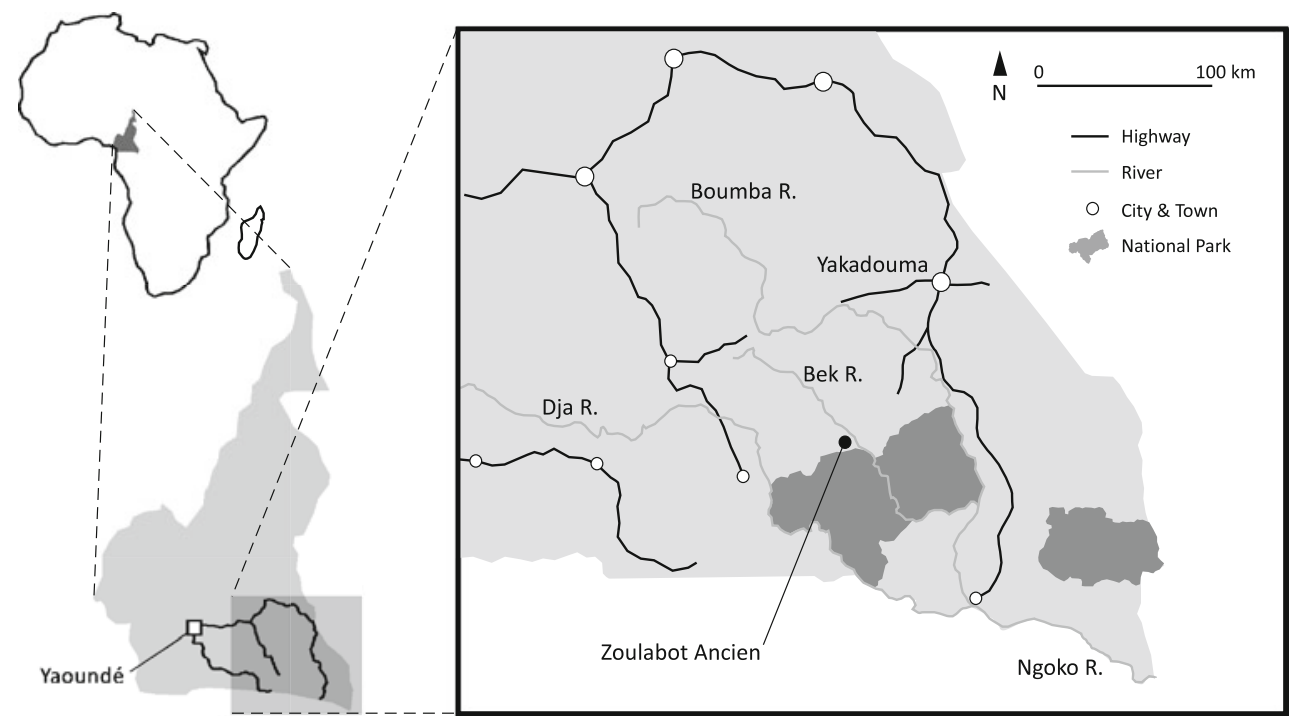

Fig. 1 Southeastern Cameroon and the study site. As well as the highways described, there are many secondary roads, most of which are constructed and maintained by logging companies

camps) I had studied in the dry seasons of 2002 and 2005 (Yasuoka 2006a, 2009a). The total period of occupation was 73 nights, of which 43 nights were spent at Mongungu camp, located $40 \mathrm{~km}$ from the village. The diet at this camp consisted solely of wild products, of which $60 \%$ (on a calorie basis) consisted of the two annual yams (Yasuoka 2006a, 2009a). The same was true for the Jalope camp in 2005 (Fig. 2). Compared to farming camps, annual yam consumption in molongo camps is considerable (Table 2) and provides more calories than the typical village diet (Yasuoka 2009a, 2012).

At both campsites 24 adjoining quadrats of $10 \times 10 \mathrm{~m}^{2}$ were set (Figs. 3 and 4). The positions of all yams were plotted, and the species name, height, and diameter of each stem were recorded. The area of the camp and the positions of huts (mongulu) were also plotted according to my previous illustrations and the recollections of Baka assistants. To calculate the density of wild yams separately inside and outside the camp, the quadrats were divided into smaller quadrats of $2.5 \times 2.5 \mathrm{~m}^{2}$, and each quadrat was assigned inside or outside the camp. As garbage was discarded within a few meters from the camp boundary, quadrats on the boundary were judged to be inside the camp.

All plant species observed in four quadrats at the center of each site were recorded. Plant names were first recorded in Baka and later their Latin names were identified

Table 1 Edible wild yams (Dioscorea spp.) in Baka land

\begin{tabular}{|c|c|c|c|c|c|}
\hline Species & Baka name & Habitat & Stem & Tuber & $\begin{array}{l}\text { Propagation } \\
\text { mainly by }\end{array}$ \\
\hline D. hirtiflora Benth. & 'è sèngغ̀ & Open area & Annual & Annual & Seed, bulbil \\
\hline D. semperflorens Uline & 'è sùmà & Forest and open area & Annual & Annual & Seed, bulbil \\
\hline D. praehensilis Benth. & sapà & Forest and open area & Annual & Annual & Seed \\
\hline D. mangenotiana Miège & ba & Forest & Biennial & Perennial & Seed \\
\hline D. burkilliana Miège & 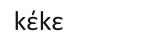 & Forest & Perennial & Perennial & Seed \\
\hline D. minutiflora Engl. & kuku & Forest & Perennial & Perennial & Stolon, seed \\
\hline D. smilacifolia De Wild. and Dur. & balj̀kj̀ & Forest & Perennial & Perennial & Stolon, seed \\
\hline D. sp. & njàkàkà & Forest & Perennial & Perennial & Stolon, seed \\
\hline D. sp. & 'è pàng $\varepsilon$ & Forest & Perennial & Perennial & Stolon, seed \\
\hline D. sp. & bolì & Forest & Perennial & Perennial & Seed \\
\hline
\end{tabular}

According to Hladik and Dounias (1993), Hamon et al. (1995), Dounias (1993, 2001), Yasuoka (2006a, 2009a) 
Table 2 Harvested wild yams in molongo long-term camps and farming camps

\begin{tabular}{|c|c|c|c|c|c|c|}
\hline \multirow[t]{3}{*}{ Species } & \multicolumn{2}{|c|}{ Molongo Mongungu camp } & \multicolumn{2}{|c|}{ Molongo Jalope camp } & \multicolumn{2}{|c|}{ Farming camp near village } \\
\hline & \multicolumn{2}{|c|}{2926.0 adult-days } & \multicolumn{2}{|c|}{1247.5 adult-days } & \multicolumn{2}{|c|}{314.5 adult-days } \\
\hline & Total (kg) & Per adult-day (g) & Total $(\mathrm{kg})$ & Per adult-day (g) & Total (kg) & Per adult-day $(\mathrm{g})$ \\
\hline D. praehensilis & 3891.0 & 1,330 & 1218.0 & 976 & 6.1 & 19 \\
\hline D. semperflorens & 654.6 & 224 & 963.2 & 772 & & \\
\hline D. burkilliana & 184.7 & 63 & 66.9 & 54 & 11.0 & 35 \\
\hline D. mangenotiana & 61.8 & 21 & 78.9 & 63 & 48.6 & 154 \\
\hline D. minutiflora & 22.7 & 8 & 2.5 & 2 & 5.5 & 17 \\
\hline D. smilacifolia & & & 1.4 & 1 & & \\
\hline Dp. cumminsii & 3.1 & 1 & 7.4 & 6 & 2.9 & 9 \\
\hline Total & 4817.8 & 1,647 & 2338.3 & 1,874 & 73.9 & 235 \\
\hline
\end{tabular}

Recalculated from the data analyzed in Yasuoka (2006a, 2009a). Dp. cumminsii is a plant that has yam-like edible tubers

(Letouzey 1976; Yasuoka 2009b; Brisson 2011; Hattori 2012). The characteristics of each plant were inferred from the knowledge of the Baka assistants.

\section{Assessment of the Light Environment of Yam Patches}

To determine the change in the light environment after the camp was abandoned, hemispherical photographs were taken on the four vertexes and the center of each quadrat in both campsites (61 points for each site, but five photographs could not be taken at the Jalope site because of the presence of a river). Each point was judged to be inside or outside of the camp according to the same criterion as the yam density estimation. In addition, $10 \times 10 \mathrm{~m}^{2}$ quadrats were set at three campsites abandoned one or a half year previously, and photographs were taken on the four vertexes and the center of each quadrat (15 points in total). Photographs were also taken in the same way in four adjoining $10 \times 10 \mathrm{~m}^{2}$ quadrats (13 points) set in mature forest with a closed canopy. Finally, as a control plot that represented general light levels
Fig. 2 Routes and camps of the molongo from Feb. 17 to Apr. 27, 2002 (Yasuoka 2006a)

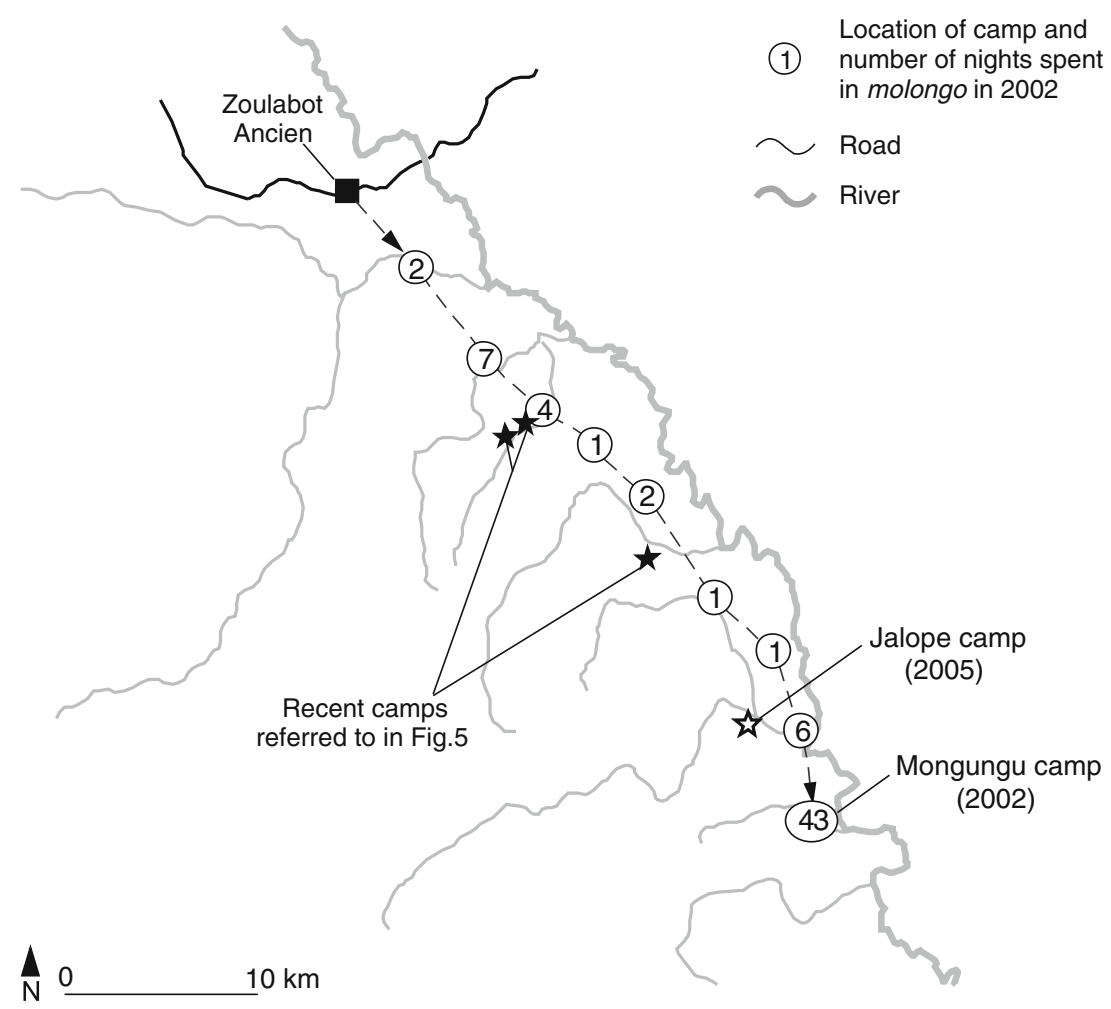


Fig. 3 Distribution of huts in 2002 (above) and wild yams in 2012 (below) at the Mongungu site
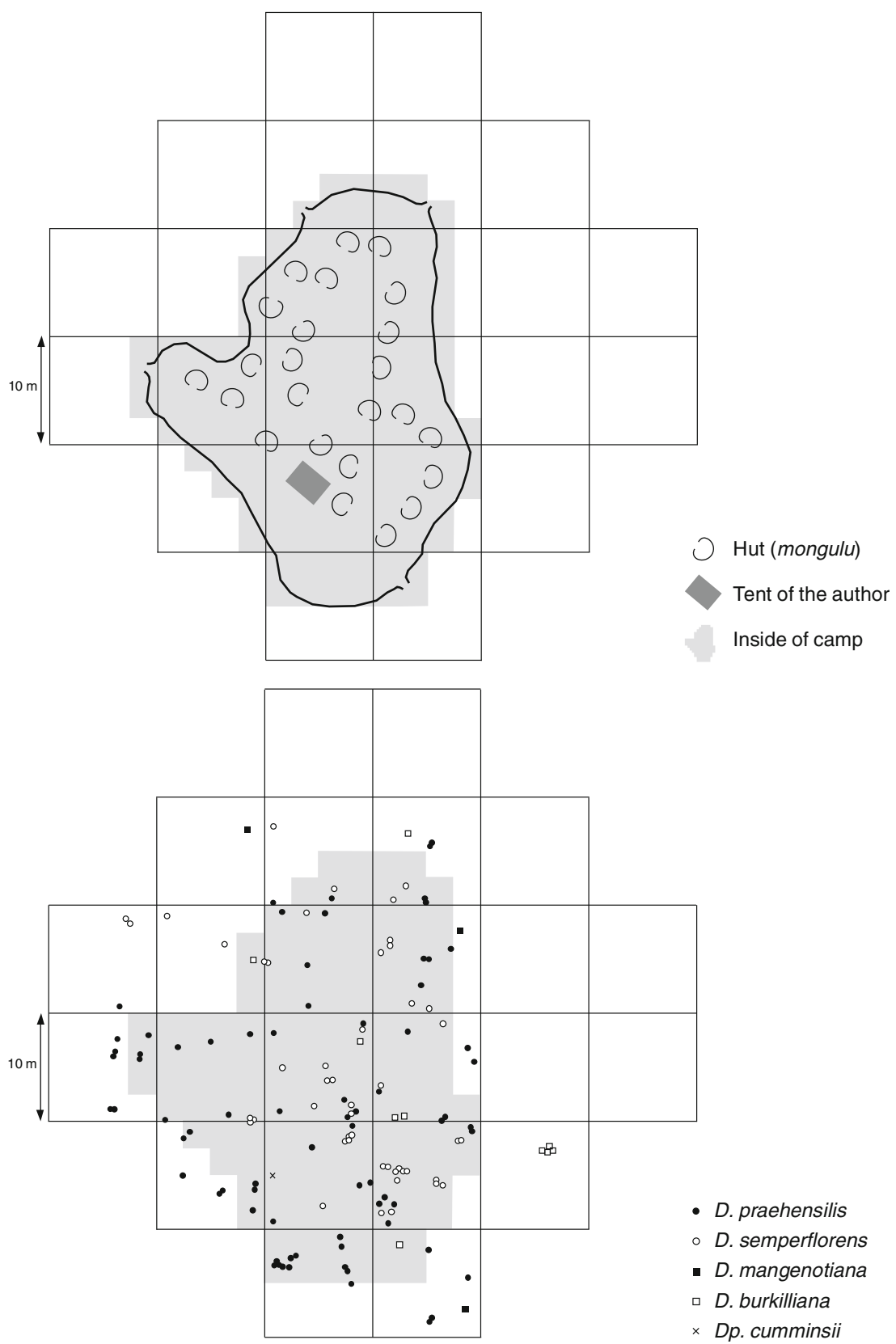

in the forest, photographs were taken on a $10 \mathrm{~m}$ grid in a quadrat of $50 \times 50 \mathrm{~m}^{2}$ set at a distance of $200 \mathrm{~m}$ from the Jalope site (36 points).

Photographs were taken with a Nikon digital camera (COOLPIX 4500) with a Nikon fisheye lens (FC-E8). The camera was positioned horizontally at $1 \mathrm{~m}$ height, and underexposed photographs were taken. CanopOn2 software (http://takenaka-akio.cool.ne.jp/etc./canopon2/) was used to compute the proportion of diffuse solar radiation reaching a given location relative to a location in the open. A standard overcast sky model was assumed, which weights each direction according to the surface of the sky vault fraction and assumes a decrease in light intensity from zenith to horizon; the zenith is three times lighter than the horizon. To compare the light levels among the plots, differences in the distributions of measured light levels were tested using the Kolmogorov-Smirnov test $(p<0.05)$.

\section{Results}

Distributions and Densities of Wild Yams

At both sites, large numbers of annual yams (D. praehensilis and $D$. semperflorens) were observed, whereas other species were much less common (Tables 3 and 4). At Mongungu, 137 stems of six species were recorded, including $75 \mathrm{D}$. praehensilis and 41 D. semperflorens (excluding seedlings). 
Fig. 4 Distribution of huts in 2005 (above) and wild yams in 2012 (below) at the Jalope site
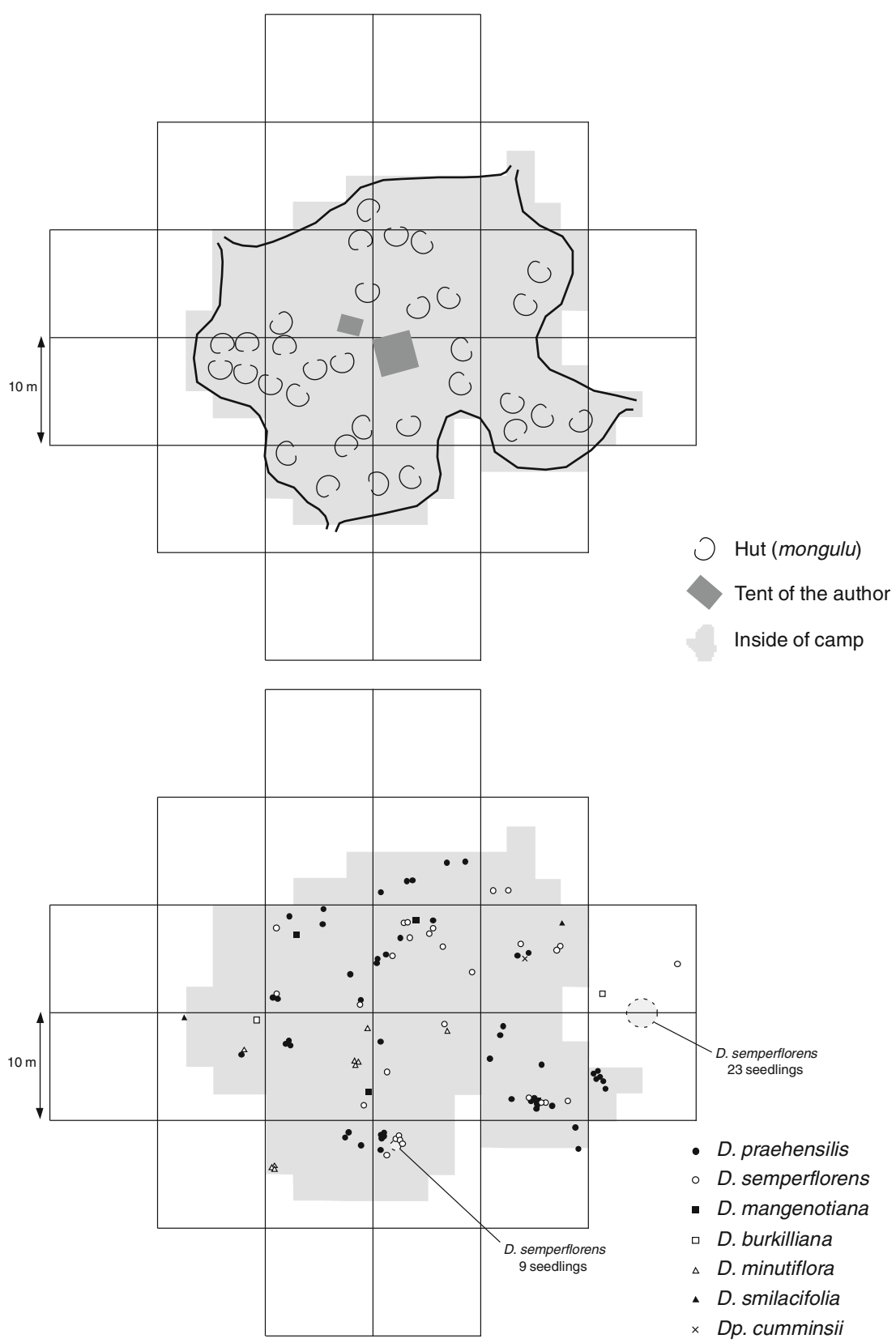

At Jalope, 129 stems of eight species were recorded, including $50 \mathrm{D}$. praehensilis and $29 \mathrm{D}$. semperflorens. It is obvious that these results correspond to the large quantities of these species consumed during molongo (Table 2).

The distribution of yams was concentrated in the inside plots at both sites (Figs. 3 and 4). For D. praehensilis and D. semperflorens, 57 and 36 stems were observed inside Mongungu camp, whereas 18 and 5 were observed outside the camp, respectively (Table 3). Similarly, 49 and 28 stems were observed inside Jalope camp, respectively, while only one stem of each species was observed outside the camp (Table 4). The respective densities of these yams in the inside plots were 661 and 417 stems/ha at Mongungu, and 509 and $291 \mathrm{stems} / \mathrm{ha}$ at Jalope. In the outside plots, their densities were much lower. The density of $D$. praehensilis in the outside plots of Mongungu exceeded 110 stems/ha, but this was only because many yams were scattered on the periphery of the camp (Fig. 3). In addition to these structured surveys, areas within $20 \mathrm{~m}$ from the quadrats at both sites were also searched, but neither $D$. praehensilis nor $D$. semperflorens was found.

These distributions of annual yams correspond to the Baka explanation of the formation of yam patches. At the camp, each woman cuts cylindrical tubers into several pieces and boils them in a pot. Harvested tubers are cooked and eaten in a couple of days, because they are quite perishable. The Baka assistants, who had participated in the molongo, stated that they had never planted yams but had discarded inedible parts of the tubers around the huts, and 
Table 3 Numbers and densities of wild yams observed at Mongungu

\begin{tabular}{|c|c|c|c|c|}
\hline \multirow[t]{2}{*}{ Species } & \multicolumn{2}{|c|}{ Inside (0.08625 ha) } & \multicolumn{2}{|c|}{ Outside (0.15375 ha) } \\
\hline & $\begin{array}{l}\text { Number } \\
\text { of stems }\end{array}$ & $\begin{array}{l}\text { Density } \\
\text { (stem/ha) }\end{array}$ & $\begin{array}{l}\text { Number } \\
\text { of stems }\end{array}$ & $\begin{array}{l}\text { Density } \\
\text { (stem/ha) }\end{array}$ \\
\hline D. praehensilis & 57 & 661 & 18 & 117 \\
\hline D. semperflorens & 36 & 417 & 5 & 33 \\
\hline $\begin{array}{l}\text { D. semperflorens } \\
\text { (seedling) }\end{array}$ & 7 & 81 & & \\
\hline D. burkilliana & 5 & 58 & 5 & 33 \\
\hline D. mangenotiana & & & 3 & 20 \\
\hline Dp. cumminsii & 1 & 12 & & \\
\hline Total & 106 & 1,229 & 31 & 202 \\
\hline $\begin{array}{l}\text { Total (excluding } \\
\text { seedlings) }\end{array}$ & 99 & 1,148 & 31 & 202 \\
\hline
\end{tabular}

Dp. cumminsii is a plant that has yam-like edible tubers

also, according to my observations, they had not planted any tubers in the camp.

\section{Light Environment}

The light levels of recently abandoned camps were significantly higher than all other plots (including the control) (Fig. 5). At Jalope, which was abandoned 7 years before the study, the light levels inside the camp were significantly higher than at the control site, whereas the measurements outside the camp were not different from the control. At Mongungu, which was abandoned 10 years before the study, the light levels both inside and outside the plots were not significantly different from the control site. This suggests that light levels revert to their original state over a period of between 7 and 10 years.

Table 4 Numbers and densities of wild yams observed at Jalope

\begin{tabular}{|c|c|c|c|c|}
\hline \multirow[t]{2}{*}{ Species } & \multicolumn{2}{|c|}{ Inside (0.09625 ha) } & \multicolumn{2}{|c|}{ Outside (0.14375 ha) } \\
\hline & $\begin{array}{l}\text { Number } \\
\text { of stems }\end{array}$ & $\begin{array}{l}\text { Density } \\
\text { (stem/ha) }\end{array}$ & $\begin{array}{l}\text { Number } \\
\text { of stems }\end{array}$ & $\begin{array}{l}\text { Density } \\
\text { (stem/ha) }\end{array}$ \\
\hline D. praehensilis & 49 & 509 & 1 & 7 \\
\hline D. semperflorens & 28 & 291 & 1 & 7 \\
\hline $\begin{array}{l}\text { D. semperflorens } \\
\text { (seedling) }\end{array}$ & 9 & 94 & 23 & 160 \\
\hline D. smilacifolia & 9 & 94 & & \\
\hline D. mangenotiana & 4 & 42 & & \\
\hline D. burkilliana & 1 & 10 & 1 & 7 \\
\hline D. minutiflora & 1 & 10 & 1 & 7 \\
\hline Dp. cumminsii & 1 & 10 & & \\
\hline Total & 102 & 1,060 & 27 & 188 \\
\hline $\begin{array}{l}\text { Total (excluding } \\
\text { seedlings) }\end{array}$ & 93 & 966 & 4 & 28 \\
\hline
\end{tabular}

Dp. cumminsii is a plant that has yam-like edible tubers
However, the plots inside Jalope were significantly different from the recently abandoned camps, and not significantly different from the outside plots or from the plots at Mongungu. This indicates that even though the light levels were still higher than at the control site, substantial ecological succession had occurred in the inside plots at Jalope. Considering the presence of a fallen tree $(50 \mathrm{~cm}$ diameter $)$ at Jalope, which fell after the camp had been abandoned, the light levels may decrease more remarkably in the same period.

The distribution of measured light levels in the control plot had a wider range, including lighter points than areas in the forest with a closed canopy, although the difference was not significant.

\section{Vegetation}

In eight quadrats from both sites, 120 species other than yams and yam-like plants were recorded. Of these, 21 appeared in five or more quadrats (Table 5). These included shade-tolerant species that had existed before the camps were established, and pioneer species that had established after the camps were abandoned. The latter included fastgrowing shrubs and trees, such as Oncoba glauca, Discoglypremna caloneura, Dichostemma glaucescens, and Tricalysia coriacea, which resulted in a decrease in light levels at the forest floor. However, they did not affect light levels in higher layers of the forest, because they were still smaller than $5 \mathrm{~m}$ in height. Indeed, the yam vines tended to climb these shrubs and use them as props.

\section{Discussion}

Human Impacts on Wild Yam Dispersal

The densities of yams in molongo campsites were much higher than recorded in previous studies conducted in the western Congo Basin, especially those recorded in mature forest, where annual yams rarely establish (Hladik et al. 1984; Hladik and Dounias 1993; Sato 2001; Yasuoka 2009a). As for disturbed environment, Dounias (2001) observed a secondary forest containing yams at a density of $393 \mathrm{stems} / \mathrm{ha}$, in which D. praehensilis was dominant; and Sato (2006) described a yam patch on an open hilltop with a density of 602 stems/ha, $94 \%$ of which were $D$. praehensilis. The densities found in the present study far exceed these values: 1,148 stems/ha at Mongungu and 966 stems/ha at Jalope (excluding seedlings), with annual yams being dominant at both sites. In addition, the high density of $D$. semperflorens was an interesting difference from the results of Dounias (2001) and Sato (2006). Obviously, this is the result of intensive consumption of 
Fig. 5 Comparison of light levels. Boxes mark median values and $25^{\text {th }}$ and $75^{\text {th }}$ percentiles, and whiskers mark the minimum and maximum. Numbers after the plot names indicate points where photographs were taken. Plots with significantly different light levels from the control plot are indicated by gray boxes (Kolmogorov-Smirnov test, $p<$ 0.05)

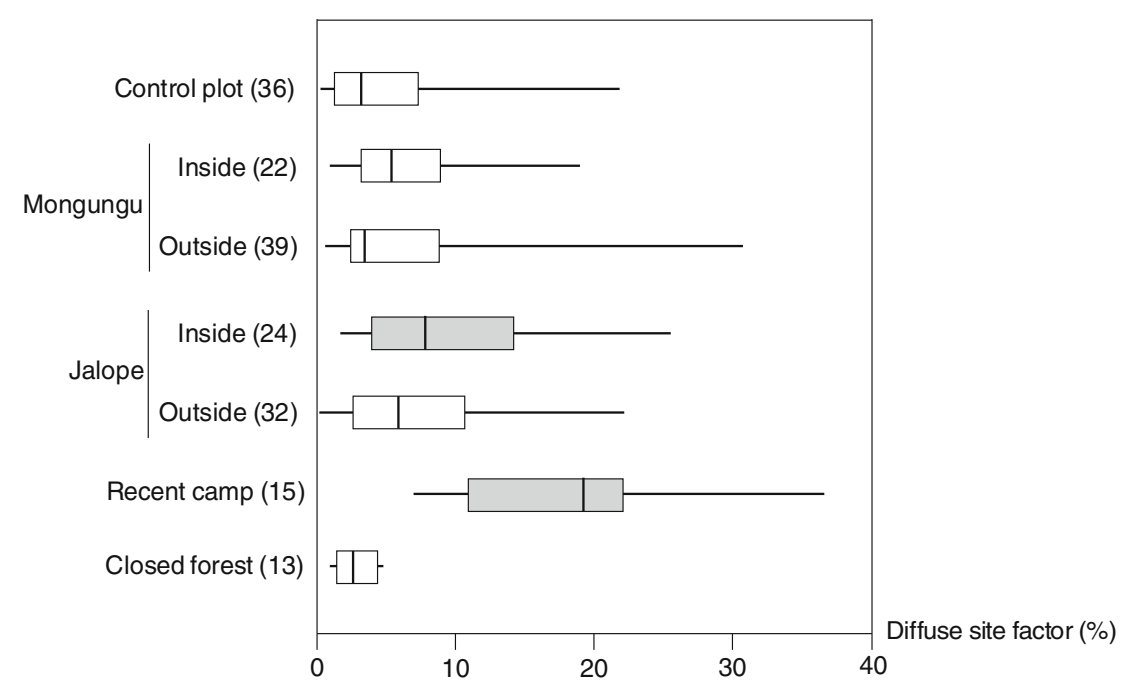

D. semperflorens, as well as D. praehensilis, in the molongo camps (Table 2).

The present study also found that light levels on the forest floor reverted to their original state within 10 years or less after camps were abandoned. Nevertheless, the improved light levels do increase the opportunity for discarded yam tuber pieces to regenerate. Once the yams have fully developed, low light levels on the ground will not affect them because the stems grow higher than the surrounding trees and the leaves are well spread. In contrast, the rapid degradation of light levels on the forest floor negatively affects the propagation of yams through true seeds (sexual propagation), which have a lower capacity to establish than tuber seeds (vegetative propagation).

Table 5 Major plant species observed at Mongungu and Jalope

\begin{tabular}{|c|c|c|c|c|}
\hline Species & Baka name & Occurrence $(0-8)$ & Habit & Habitat \\
\hline Aframomum spp. (Zingiberaceae) & njíyi & 8 & Herb & Gap \\
\hline Haumania danckelmaniana (Marantaceae) & kpàscle & 8 & Liana & Gap \\
\hline Rinorea welwitschii (Violaceae) & ngindi & 8 & Shrub & Shade \\
\hline Scorodophloeus zenkeri (Caesalpinioideae) & mìngغ̀gyè & 7 & Tree & Shade \\
\hline Tricalysia coriacea (Rubiaceae) & 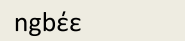 & 7 & Shrub & Gap \\
\hline Millettia sanagana (Faboideae) & ngánda & 7 & Shrub & Shade \\
\hline Streblus usambarensis (Moraceae) & ndúndu & 7 & Shrub & Shade \\
\hline Sarcophrynium brachystachyum (Marantaceae) & ngoasa & 7 & Herb & Gap \\
\hline Discoglypremna caloneura (Euphorbiaceae) & jilà & 6 & Tree & Gap \\
\hline Oncoba glauca (Flacourtiaceae) & gbàgòl’̀ & 6 & Shrub & Gap \\
\hline Lasiodiscus mannii (Rhamnaceae) & èsumà & 6 & Shrub & Shade \\
\hline Xylopia sp. (Annonaceae) & gbegbele & 6 & Shrub & Shade \\
\hline Hypselodelphys zenkeriana (Marantaceae) & lìngòmbè & 6 & Liana & Gap \\
\hline Rourea obliquifoliolata (Connaraceae) & túkusà & 6 & Liana & Shade \\
\hline Dichostemma glaucescens (Euphorbiaceae) & mòngamba & 5 & Tree & Gap \\
\hline Alchornea floribunda (Euphorbiaceae) & yàndo & 5 & Shrub & Shade \\
\hline Anthonotha macrophylla (Caesalpinioideae) & popolo & 5 & Shrub & Shade \\
\hline Manniophyton fulvum (Euphorbiaceae) & kusa & 5 & Liana & Gap \\
\hline Millettia barteri (Faboideae) & mòkskJdi & 5 & Liana & Shade \\
\hline Leptaspis cochleata (Gramineae) & ndingbelengbe & 5 & Herb & Gap \\
\hline Palisota megaphylla (Commelinaceae) & njayà & 5 & Herb & Gap \\
\hline
\end{tabular}

Grey band indicates the trees and shrubs of pioneer species that have grown up after the camping. This table excluedes wild yam species 
Moreover, yam plants remained in and around the camps for 7-10 years after their initial establishment. This indicates that their large-scale propagation has not succeeded, or at least its extent is limited. These results also support the argument that the dispersal ability of annual yams is too low to vigorously colonize forest gaps (Yasuoka 2009a). Therefore, it is likely that the discarding of tubers created dense yam patches in areas that lack wild yams. These results suggest that exploiting annual yams substantially contributes to their dispersal, and that annual yams have been dispersed principally by hunter-gatherers.

\section{Dispersal of Annual Yams by Hunter-Gatherers}

There are two important points to note about the dispersal of yams through the activity of the Baka. First, the scattering of the parts of the tubers that are always cut off when yams are cooked is sufficient to create a yam patch. Although the Baka do not have any clear intention to create yam patches in this way, they understand that patches will develop after a molongo camp has been abandoned. However, even if they did not recognize the significance of this process, the Baka or their ancestors would have dispersed yams once they began eating them.

Second, this is a direct introduction of tuber seeds into a new habitat. This point is important because annual yams have low dispersal abilities and at the same time they prefer forest gaps with high light levels (Yasuoka 2009a). It has been suggested that Bantu cultivators' land use practices, which induce larger forest disturbances, may have influenced the dispersal of annual yams (Yasuoka 2009a). However, the cultivators, whose food staples consist largely of plantains and cassava, do not grow wild yams in their fields at present, and it is likely that they have never planted them. As noted above, the dispersal of annual yams through true seeds is much less efficient than that through tubers. Therefore, it is likely that the consumption of annual yams by hunter-gatherers would have contributed to their dispersal through the forest.

\section{The Ecological Basis of Molongo}

The results also indicate that there is an ecological basis of molongo, which can be explained at least partially through the Baka's exploitation of yams. The next question is whether enough yam patches to support a series of annual molongo can be generated solely by the activity of the molongo itself.

First, the number of yam patches required for an annual molongo was estimated assuming a group of 50 people (the average size of a Baka settlement) (Sato 1992; Tsuru 1998). The daily food consumption of 50 people is equivalent to that of 35 adults, assuming the same ratio of children that I identified in earlier work (2006a, 2009a). An adult eats $1.5 \mathrm{~kg}$ of tubers a day (Table 2); therefore, 35 adults will consume $9,450 \mathrm{~kg}$ in 180 days during the November to April period when annual yam tubers remain at their maximum size (Dounias 2001; Yasuoka 2006a). On average, a D. praehensilis plant produces tubers of $6.6 \mathrm{~kg}$ (Yasuoka 2009a) or $4 \mathrm{~kg}$ (Dounias 2001) and a D. semperflorens plant produces tubers of $3.1 \mathrm{~kg}$ (Yasuoka 2009a). Here, it is assumed that each plant produces $3 \mathrm{~kg}$ of tubers. A yam patch contains a combined total of 100 plants of $D$. praehensilis and D. semperflorens (Tables 3 and 4), so it provides $300 \mathrm{~kg}$ of tubers. Therefore, 32 patches are required to produce $9,450 \mathrm{~kg}$ of tubers. However, since a 3year interval is required to produce a sustainable harvest (Dounias 2001; Yasuoka 2006a), 96 patches are required for an annual 6-month-long molongo by 50 people.

Next, how long a patch needs to persist was considered. Generally, the Baka change campsites every two months (Yasuoka 2006b), so a 6-month-long molongo includes three long-term camps and the subsequent generation of three yam patches. If the patches can be used repeatedly for 32 years on average, the stocks from 96 patches are always available for the Baka to carry out 6-month-long molongo every year. Therefore, we need to determine whether ecological succession progresses to the point that photosynthesis becomes difficult for annual yams due to competing plants and resulting reduction in available light. Light levels on the ground revert to the original state within 10 years after a camp is abandoned due to fast-growing shrubs reaching a height of $5 \mathrm{~m}$ (Fig. 5). However, this period is sufficient for new yam plants to regenerate and grow over surrounding shrubs. Moreover, the Baka often cut down several trees 10 to $15 \mathrm{~m}$ in height during their stay in a camp, which improves the light levels in the middle layer that are maintained for longer than on the ground. Therefore, it is likely that once a yam patch is established, it will persist for 30 years or more.

The estimated density of yam patches under these assumptions corresponds to field observations. To provide wild yams for 50 people for 2 months (2,100 adult-days), 10.7 patches are needed (cf. 32 patches for 6 months). In total, 11 patches were observed within a radius of $3 \mathrm{~km}$ (about $28 \mathrm{~km}^{2}$ ) of the Jalope molongo camp, where 1247.5 adult-days were spent (Yasuoka 2009a). Assuming a yam patch density of $0.4(=10.7 / 28)$ per square kilometer, a forest of $320 \mathrm{~km}^{2}$ would contain 96 patches, which meets the requirements of the annual 6-month-long molongo for 50 people. The population density is then $0.15(=50 / 320)$ per square kilometer. This is also similar to the density observed at the study site, where an area of $1,000 \mathrm{~km}^{2}$ was used by 
200 people $\left(0.2\right.$ people $\left./ \mathrm{km}^{2}\right) .{ }^{1}$ These results suggest that enough yam patches to support the annual molongo can be generated wholly by the activity of the molongo itself.

\section{Toward the Historical Ecology of Rainforests}

On this basis, it is possible to move beyond the dichotomy between pure hunter-gatherer subsistence and a dependence on agriculture. As noted above, studies in southeastern Cameroon have indicated that sufficient wild yams were available for hunter-gatherer subsistence throughout the year (Sato 2001, 2006; Yasuoka 2006a, 2012; Sato et al. 2012), and the results presented here conclusively show that the activities hunter-gatherers themselves generate this sufficiency.

More importantly, this study provides two conclusions that advance the historical ecology of the African rainforests. First is the significance of "semi-cultivated" resources, which are not domesticated but persist under substantial interactions with humans. This study suggests that hunter-gatherers have depended on the rainforest ecosystem as a habitat through the exploitation of resources such as wild yams along a continuum ranging between pure gathering and complete cultivation depending on local conditions.

"Para-cultivation" of wild yams (Dounias 2001) is an example of such variability. The Baka sometimes rebury part of a yam tuber with the intention of promoting its regeneration. As Dounias (2001) emphasized, paracultivation does not necessarily lead to complete cultivation but rather remains in an initial state or can revert back to a gathering state if conditions change. Compared to the period when the Baka lived in smaller and migratory settlements in the forest, the population is now more concentrated around the village, and it is unlikely that the Baka's exploitation has led to the accumulation of enough genetic mutations in yams to adapt to conditions under high population density (Yasuoka 2012). Without para-cultivation as the case in Zoulabot Ancien, to maintain yam patches requires considerable distances between settlements and yam patches to avoid negative human impacts on the formation of yam patches.

The second conclusion is a consequence of external factors in the distribution of forest resources. The Baka's resource use and thus the distribution of annual yams have been influenced by a variety of political and economic factors, i.e., their relationship with cultivators, sedentarization, road construction, commercial logging, and forest conservation projects. If the Baka were not sedentarized, their method of

\footnotetext{
${ }^{1}$ Bahuchet et al. (1991) estimated the density of the Aka in the Central African Republic to be 0.1 people $/ \mathrm{km}^{2}$.
}

yam exploitation would be different. The molongo I described in earlier work (2006a) is neither their original hunting-and-gathering lifestyle nor the pure hunting-andgathering lifestyle that depends heavily on the environment.

For other Pygmy groups that do not engage in molongo, it is possible that yam patches were developed but then disappeared with changes in resource use. The Aka, in northern Congo-Brazzaville, do not eat $D$. praehensilis as frequently as the Baka, and they also consume considerable amounts of agricultural crops during the dry season (Kitanishi 1995). For the Mbuti, in eastern Congo-Kinshasa, the dry season is their hunting season and they obtain agricultural crops in exchange for the meat they hunt (Ichikawa 1983). However, the current absence of yam patches does not necessarily mean they never existed.

Yam patches in southeastern Cameroon can also diminish if the Baka cease using them. There are two significant factors that decrease the frequency of molongo. One is the expansion of cultivation. The dry season is the suitable period for clearing fields and it falls within the molongo season. The second factor is the forest conservation projects that have been promoted since the 1990s (Ichikawa 2006; Njounan Tegomo et al. 2012). In 2005, Nki National Park was established adjacent to Zoulabot Ancien (Fig. 1) and molongo became illegal because camping in national parks is prohibited.

The molongo of the Baka presents a challenge in understanding and preserving the inscribed histories of interactions between the people and forest resources of the African rainforests. This challenge must be addressed to improve existing forest conservation schemes, which have significant and often negative effects on the lives of forest peoples.

Acknowledgments This research was supported by JSPS Postdoctoral Fellowships for Research Abroad (Hosted by Dr. Edmond Dounias), JSPS KAKENHI No. 24710296, and JST/JICA SATREPS FOSAS project.

Open Access This article is distributed under the terms of the Creative Commons Attribution License which permits any use, distribution, and reproduction in any medium, provided the original author(s) and the source are credited.

\section{References}

Althabe, G. (1965). Changements Sociaux Chez les Pygmées Baka de 1'Est-Cameroun. Cahiers d'Etudes Africaines 2(5): 561-592.

Bahuchet, S., McKey, D., and De Garine, I. (1991). Wild Yams Revisited: Is Independence from Agriculture Possible for Rain Forest Hunter-Gatherers? Human Ecology 19(2): 213-243.

Bailey, R. C., and Headland, T. N. (1991). The Tropical Rain Forest: Is it a Productive Environment for Human Foragers? Human Ecology 19(2): 261-285.

Bailey, R. C., Head, G., Jenike, M., Owen, B., Rechtman, R., and Zechenter, E. (1989). Hunting and Gathering in Tropical Forest: Is it Possible? American Anthropologist 91(1): 59-82. 
Brisson, R. (2011). Utilisation des Plantes par les Pygmées Baka. L'Harmattan, Paris.

Chujo, H. (1992). Ecology of the Tropical Semi-Deciduous Forest and its Possibility of the Sustaining Use in East Cameroon, West Africa (in Japanese). African Studies 41: 23-45.

Dounias, E. (1993). Perception and use of wild yams by the Baka hunter-gatherers in South Cameroon. In Hladik, C. M., Hladik, A., Licares, O. F., Pagezy, H., Semple, A., and Hadley, M. (eds.), Tropical Forests, People and Food: Biocultural Interactions and Applications to Development. UNESCO, Paris, pp. 621-632.

Dounias, E. (2001). The Management of Wild yam Tubers by the Baka Pygmies in Southern Cameroon. African Study Monographs 26: 135-156. Suppl.

Dumont, R. (1997). Domestication des ignames en Afrique. In Berthaud, J., Bricas, N., and Marchand, J. L. (eds.), L'ignames, Plante Séculaire et Culture d'avenir. CIRAD, INRA, ORSTOM, and CORAF, Montpellier, pp. 119-126.

Dumont, R., Hamon, P., and Seignobos, C. (1994). Les Ignames au Cameroun. CIRAD, Montpellier.

Hamon, P., Dumont, R., Zoundjihekpon, J., Tio-Toure, B., and Hamon, S. (1995). Les Ignames Sauvages d'Afrique de l'Ouest: Caracteristiques Morphologiques. ORSTOM, Paris.

Hart, T. B., and Hart, J. A. (1986). The Ecological Basis of HunterGatherer Subsistence in African Rain Forests: The Mbuti of Eastern Zaire. Human Ecology 14(1): 29-55.

Hattori, S. (2012). Challenge for the Coexistence of Forest and People. CAAS, Kyoto University, Kyoto.

Headland, T. N. (1987). The Wild Yam Question: How Well Could Independent Hunter-Gatherers Live in a Tropical Rain Forest Ecosystem? Human Ecology 15(4): 463-491.

Hewlett, B. S. (1996). Cultural diversity among African Pygmies. In Susan, K. (ed.), Cultural Diversity Among Twentieth-Century Foragers: An African Perspective. Cambridge University Press, Cambridge, pp. 215-244.

Hladik, A., and Dounias, E. (1993). Wild yams of the African forest as potential food resources. In Hladik, C. M., Hladik, A., Licares, O. F., Pagezy, H., Semple, A., and Hadley, M. (eds.), Tropical Forests, People and Food: Biocultural Interactions and Applications to Development. UNESCO, Paris, pp. 163-176.

Hladik, A., Bahuchet, S., Ducatillion, C., and Hladik, C. M. (1984). Les Plantes à Tubercules de la Forêt Dense d'Afrique Centrale. Revue d'Ecologie. Revue d'Ecologie (Terre et Vie) 39: 249-290.

Ichikawa, M. (1983). An Examination of the Hunting-Dependent Life of the Mbuti Pygmies. African Study Monographs 4: 55-76.

Ichikawa, M. (2006). Problems in the Conservation of Rainforests in Cameroon. African Study Monographs 33: 3-20. Suppl.

Kitanishi, K. (1995). Seasonal Changes in the Subsistence Activities and Food Intake of the Aka Hunter-Gatherers in Northeastern Congo. African Study Monographs 16(2): 73-118.

Letouzey, R. (1976). Contribution de la Botanique au Problème d'une Eventuelle Langue Pygmée. SELAF, Paris.

Letouzey, R. (1985a). Carte Phytogéographique du Cameroun au 1:500000. Institute de la Recherche Agronomique (Herbier National), Toulouse.

Letouzey, R. (1985b). Notice de la Carte Phytogéographique du Cameroun au 1:500000. Institute de la Recherche Agronomique (Herbier National), Toulouse.

McKey, D., Digiusto, B., Pascal, M., Elias, M., and Dounias, E. (1998). Stratégies de croissance et de défense anti-herbivore des ignames sauvages: leçons pour l'agronomie. In Berthaud, J.,
Bricas, N., and Marchand, J.-L. (eds.), L'Igname, Plante Séculaire et Culture d'Avenir. CIRAD, Montpellier, pp. 181-188.

Mercader, J. (2003a). Introduction: the Paleolithic settlement of rain forest. In Mercader, J. (ed.), Under the Canopy: The Archeology of Tropical Rain Forests. Rutgers University Press, New Brunswick, pp. $1-31$

Mercader, J. (2003b). Foragers of the Congo: the early settlement of the Ituri forest. In Mercader, J. (ed.), Under the Canopy: The Archeology of Tropical Rain Forests. Rutgers University Press, New Brunswick, pp. 93-116.

Mercader, J., and Martí, R. (2003). The middle stoneage occupation of Atlantic Central Africa: new evidence from Equatorial Guinea and Cameroon. In Mercader, J. (ed.), Under the Canopy: The Archeology of Tropical Rain Forests. Rutgers University Press, New Brunswick, pp. 64-92.

Njounan Tegomo, O., Defo, L., and Usongo, L. (2012). Mapping of Resource use Area by the Baka Pygmies Inside and Around Boumba-Bek National Park in Southeast Cameroon, with Special Reference to Baka's Customary Rights. African Study Monographs 43: 45-59. Suppl.

Sato, H. (1992). Notes on the Distribution and Settlement Pattern of Hunter-Gatherers in Northeastern Congo. African Study Monographs 13(4): 203-216.

Sato, H. (2001). The Potential of Edible Wild Yams and Yam-Like Plants as a Staple Food Resource in the African Tropical Rain Forest. African Study Monographs 26: 123-134. Suppl.

Sato, H. (2006). A Brief Report on a Large Mountain-Top Community of Dioscorea Praehensilis in the Tropical Rainforest of Southeastern Cameroon. African Study Monographs 33: 21-28. Suppl.

Sato, H., Kawamura, K., Hayashi, K., Inai, H., and Yamauchi, T. (2012). Addressing the Wild Yam Question: How Baka HunterGatherers Acted and Lived During Two Controlled Foraging Trips in the Tropical Rainforest of Southeastern Cameroon. Anthropological Science 120(2): 129-149.

Tsuru, D. (1998). Diversity of Ritual Spirit Performances Among the Baka Pygmies in Southeastern Cameroon. African Study Monographs 25: 47-84. Suppl.

van Gemerden, B. S., Olffm, H., Parren, M. P. E., and Bongers, F. (2003). The Pristine Rain Forest? Remnants of Historical Human Impacts on Current Tree Species Composition and Diversity. Journal of Biogeography 30: 1381-1390.

Yasuoka, H. (2006a). Long-Term Foraging Expedition (Molongo) Among the Baka Hunter-Gatherers in the Northwestern Congo Basin, with Special Reference to the "Wild Yam Question". Human Ecology 34(2): 275-296.

Yasuoka, H. (2006b). The Sustainability of Duiker (Cephalophus spp.) Hunting for the Baka Hunter-Gatherers in Southeastern Cameroon. African Study Monographs 33: 95-120. Suppl.

Yasuoka, H. (2009a). Concentrated Distribution of Wild Yam Patches: Historical Ecology and the Subsistence of African Rainforest Hunter-Gatherers. Human Ecology 37(5): 577587.

Yasuoka, H. (2009b). The Variety of Forest Vegetations in Southeastern Cameroon, with Special Reference to the Availability of Wild Yams for the Forest Hunter-Gatherers. African Study Monographs 30(2): 89-119.

Yasuoka, H. (2012). Fledging Agriculturalists? Rethinking the Adoption of Cultivation by the Baka Hunter-Gatherers. African Study Monographs 43: 85-114. Suppl. 